\title{
Alclometasone Dipropionate
}

National Cancer Institute

\section{Source}

National Cancer Institute. Alclometasone Dipropionate. NCI Thesaurus. Code C47385.

The dipropionate salt form of alclometasone, a synthetic corticosteroid with low to medium potency. Alclometasone dipropionate is a glucocorticoid receptor agonist that mimics the metabolic, anti-inflammatory, immunosuppressive, antipruritic, and vasoconstrictive effects of natural glucocorticoids. This drug interacts with specific intracellular receptors and binds to DNA to modify gene expression. This results in an induction of synthesis of certain proteins while inhibiting the synthesis of others. Alclometasone dipropionate is used for the relief of the inflammatory and pruritic manifestations of corticosteroid-responsive dermatoses. ( $\mathrm{NCI05)}$ 